\title{
KERATON AGUNG SEJAGAT DAN REPRESENTASI PARA AKTOR SOSIALNYA DALAM WACANA BERITA DI KOMPAS.COM
}

\author{
(Keraton Agung Sejagat and The Representation of Its Social Actors \\ in Kompas.com News Discourse) \\ R. Hery Budhiono \\ Balai Bahasa Kalimantan Tengah \\ Jalan Tingang, Km 3,5, Palangka Raya, Kalimantan Tengah 73112 \\ Posel: ralph.herybudhiono@kemdikbud.go.id
}

(Naskah Diterima Tanggal 2 Maret 2020_Direvisi Tanggal 21 Mei 2020_Disetujui Tanggal 21 Mei 2020)

\begin{abstract}
The appearance of some new kingdoms in Indonesia seized public's attention. The media then covered and published the issue to the readers. Some perspectives used in gaining and reporting the news. One of their focuses is how to represent any social actors involved. This paper will discuss what techniques used by the writer in representing any social actors in two news article deal with Keraton Agung Sejagat released by Kompas.com. The aim is to give description what techniques used and its implication to the news as a whole. Critical Discourse Analysis will be the domain of the paper, meanwhile van Leeuwen's view of social actors will be the core. This qualitative-descriptive paper is conducted in three stages, which is data providing, analysis, and the presentation of the analysis. Based on the analysis, there are eleven techniques used, i.e. exclusion, inclusion, activation, pasivation, genericization, specification, nomination, categorization and personalization.
\end{abstract}

Keywords: Critical Discourse Analysis, Keraton Agung Sejagat, social actors, discourse, mass media language

\begin{abstract}
Abstrak
Munculnya beberapa "kerajaan baru" di Indonesia sempat menyita perhatian publik pada akhir 2019_ awal 2020. Media massa pun berlomba meliput dan menyajikannya kepada khalayak pembaca dengan berbagai sudut pandang. Salah satu yang digunakan para penulis berita ialah representasi para aktor sosial yang terlibat dalam wacana pemberitaan itu. Makalah ini akan membahas penggunaan teknik penulis berita di media daring Kompas.com dalam merepresentasikan para aktor sosial dalam dua pemberitaan tentang Keraton Agung Sejagat. Tujuannya ialah memberikan gambaran teknik dan implikasinya terhadap pemaknaan berita. Metode analisis wacana kritis, terutama pandangan van Leeuwen tentang aktor sosial, digunakan untuk menganalisis dua pemberitaan itu. Hasilnya menunjukkan bahwa ada sebelas teknik yang digunakan penulis dalam merepresentasikan aktor sosial, yaitu eksklusi, inklusi, aktivasi, pasivasi, generalisasi, spesifikasi, nominasi, kategorisasi, dan personalisasi.

Kata kunci: Analisis Wacana Kritis, Keraton Agung Sejagat, aktor sosial, wacana, bahasa media massa

\section{PENDAHULUAN}

Beberapa bulan yang lalu, tepatnya pada akhir bulan Desember 2019 hingga akhir Januari 2020, bangsa Indonesia dikejutkan oleh munculnya beberapa "kerajaan baru". Pemberitaan Keraton Agung Sejagat di Purworejo, Kesultanan Selecau di Tasikmalaya, Sunda Empire di Bandung,

hingga King of The King di Tangerang ramai menghiasi media lokal, nasional, bahkan internasional, dari media cetak konvensional hingga media daring. Pembicaraan publik kemudian mengarah kepada satu simpulan. Mengapa "kerajaankerajaan" tersebut ada secara tiba-tiba? Mungkinkah mereka sebenarnya sudah lama ada, tetapi takterhiraukan?
\end{abstract}


Media massa di Indonesia ramairamai memberitakan fenomena munculnya beberapa kerajaan itu. Berbagai macam cara pun mereka lakukan untuk mengemas berita semenarik mungkin. Segala daya upaya dilakukan termasuk mengonfirmasi kepada para tokoh kerajaan di Nusantara tentang kemungkinan adanya kerajaan-kerajaan baru. Berbagai opini dan pendapat dari para pakar sejarah juga dikumpulkan untuk memperkuat presentasi berita.

Salah satu "kerajaan" yang sempat menghebohkan ialah Keraton Agung Sejagat. "Kerajaan" tersebut berbasis di Desa Pogung Juru Tengah, Kecamatan Bayan, Kabupaten Purworejo. "Kerajaan" itu didirikan oleh Toto Santoso dan Fanni Aminadia pada 2018 dan sampai dengan saat itu pengikutnya berjumlah sekitar 450 orang. Pertengahan Januari 2020, karena dituduh meresahkan masyarakat dan menunjukkan indikasi penipuan, polisi akhirnya menyudahi eksistensi kerajaan ini dan menetapkan dua pendirinya sebagai tersangka.

Fokus penting dalam penyajian berita-berita tersebut ialah representasi para pendiri kerajaan itu dalam sajian berita mereka di media cetak dan/atau daring. Representasi dua sosok utama di balik Keraton Agung Sejagat dari sudut pandang wacana kritis menjadi bahasan dalam tulisan ini. Tujuannya ialah mendeskripsikan bagaimana para sosok utama di Kerajaan Agung Sejagat direpresentasikan atau disajikan kepada khalayak.

Keraton Agung Sejagat dipilih karena pemberitaannya merupakan yang pertama dari rangkaian berita munculnya "kerajaankerajaan baru" di Indonesia. Setelah Keraton Agung Sejagat diberitakan, muncullah beberapa "kerajaan" baru, seperti Sunda Empire dan Kesultanan Selecau.

Para pelibat dalam sebuah peristiwa, orang-orang yang berkontribusi terhadap terjadinya sebuah peristiwa, disebut sebagai aktor sosial oleh van Leeuwen (van
Leeuwen, 2008:24). Para aktor sosial ini, yang terlibat secara langsung dan tidak langsung, menjadi pemain dalam sebuah peristiwa. Mirip sebuah drama, pada pokoknya mereka berbagi peran. Ada yang berperan sebagai tokoh utama, ada pula yang figuran. Ada yang menjadi korban, ada juga yang menjadi pelaku. Semua melebur menjadi satu dan membentuk jalan cerita sebuah peristiwa.

Pemilihan topik ini didasarkan pada pendapat para pakar yang dikutip oleh Sobur yang mengatakan bahwa media sama sekali tidak netral. Apa yang tampil di media merupakan cerminan ideologi dan kebijakan redaksional media itu. Gaya apa yang diterapkan dalam menyajikan sebuah berita tentu juga dilandasi oleh pertimbangan lain, dalam hal ini kepentingan media sendiri. Media merekonstruksi sebuah peristiwa dengan dilandasi oleh kepentingan ideologi mereka sendiri (Sobur, 2002:30).

Salah satu media daring yang cukup gencar menyajikan berita tentang Keraton Agung Sejagat ialah Kompas.com. Kompas.com yang merupakan media daring nasional terbesar di Indonesia dikenal sebagai media yang mengedepankan nasionalisme dan pluralitas. Dikutip dari https://id.wikipedia.org/wiki/Kompas.comK ompas.com merupakan portal berita terpopuler di Indonesia dan merupakan bagian dari Kompas Gramedia. Diluncurkan pada 14 September 1995, Kompas.com mengusung semboyan "Jernih Melihat Dunia". Pangsa pasar Kompas.com, seperti media daring lain, ialah mereka yang melek teknologi dan menuntut kemutakhiran informasi setiap saat. Dengan kata lain, konsumennya sebagian besar berasal dari kalangan menengah ke atas.

Dua berita yang dipilih untuk dijadikan bahan analisis dalam tulisan ini ialah "Fakta Raja Keraton Agung Sejagat, Buka Angkringan, Shooting Film Era Kerajaan, dan Dikukuhkan di Dieng" yang dirilis pada 16 Januari 2020 pukul 05:45 WIB dan "Ratu Keraton Agung Sejagat 
Bertugas Rancang Pernak Pernik Kerajaan" yang ditayangkan pada 16 Januari 2020 pukul 06.01 WIB. Kedua berita itu ditayangkan pada hari yang sama, tetapi pada waktu yang berbeda. Kedua berita tersebut dipilih karena secara lengkap menjelaskan dan mendeskripsikan dua aktor sosial utama yang merupakan pendiri "kerajaan" tersebut.

Salah satu pakar yang menginisiasi analisis wacana kritis, Theo van Leeuwen, mengatakan bahwa media yang berorientasi pada kalangan menengah ke atas biasanya lebih menonjolkan peran pemerintah dibandingkan aktor sosial yang lain. Pemerintah selalu dikedepankan. Mereka biasanya dideskripsikan secara spesifik berupa nama diri, gelar, jabatan, dan sebagainya. Sebaliknya, media yang berorientasi pada kalangan menengah ke bawah biasanya memberitakan peristiwa dari perspektif korban atau mereka yang cenderung dirugikan. Pemberitaan yang disajikan biasanya dititikberatkan pada korban dan bagaimana ciri-ciri spesifik dan sosial korban. Peran pemerintah diminimalkan sebagai salah satu upaya untuk memfokuskan pemberitaan kepada peran korban. Korban dalam sudut pandang ini dijelaskan secara lebih detail daripada aktor sosial yang lain (van Leeuwen, 2008:35).

Lebih lanjut van Leeuwen mengatakan bahwa inti dari sebuah peristiwa ialah urutan kejadian atau yang disebutnya urutan aksi sosial. Peristiwa sesederhana dan sesepele apa pun atau serumit dan sepenting apa pun merupakan urutan kejadian yang diperagakan oleh para aktor sosialnya. Oleh karena itu, dalam menulis berita, ada beberapa cara dalam menyajikan atau merepresentasikan para aktor sosial yang terlibat dalam sebuah peristiwa. Teknik yang digunakan penulis dalam mencerminkan kompromi antara pentingnya sebuah informasi, kesesuaian dengan ideologi media itu, aturan dari pemerintah, dan unsur-unsur yang lain.
Cara Kompas.com memberitakan peristiwa munculnya Keraton Agung Sejagat, jika dilihat dari dua berita yang dijadikan percontoh, cukup mewakili pandangan van Leeuwen. Dalam hal merepresentasikan aktor sosial, Kompas.com lebih banyak menitikberatkan bahasan pada dua aktor utama. Peran dan representasi pemerintah, dalam berita itu diwakili oleh Polda Jawa Tengah, tidak terlalu ditonjolkan. Adanya realita ini menunjukkan bahwa Kompas.com hendak mendekatkan diri kepada kalangan menengah ke bawah.

Leech dan Short via Mills mengatakan bahwa wacana adalah sebuah komunikasi bahasa yang dilihat sebagai sebuah transaksi antara pembicara dan pendengar serta sebagai aktivitas antarpersonal yang bentuk dan tujuannya ditentukan oleh tujuan sosial. Wacana bukan lain ialah penggunaan praktis bahasa dan semestinya dipelajari dalam ranah penggunaanya tersebut (Mills, 1997:4). Lebih lanjut, Talbot dalam Mayr mengatakan bahwa teks mengacu kepada produk interaksi yang dapat diamati, sedangkan wacana ialah proses interaksi yang terjadi di dalamnya yang sejatinya merupakan aktivitas budaya. Oleh karena itu, penting untuk diresapi bahwa memandang teks tidak akan lepas dari konteks budaya karena sesungguhnya konteks (Halliday \& Hasan, 1992:6; Mayr, 2008:7).

Pengertian tentang analisis wacana kritis berbeda dengan pandangan tradisional yang mengatakan bahwa teks hanya sebuah tulisan atau bahasa ragam tertulis, tidak berarti, dan terpisah dari konteks (Halliday \& Hasan, 1992:6; Fairclough, 1995:4; Wodak, 2001a:65; van Leeuwen, 2008:6). Bertolak dari pandangan inilah kemudian Fairclough dan rekan-rekannya mengajukan suatu studi yang mengorelasikan bahasa, kekuasaan, dan ideologi. Oleh karena itu, definisi yang diajukan oleh Fairclough tentang analisis wacana kritis ialah integrasi antara analisis teks, bagaimana teks 
diproduksi, dan analisis sosial budaya terhadap peristiwa wacana tersebut (Fairclough, 1995:23).

Habermas mengatakan bahwa bahasa merupakan media untuk mendominasi dan menunjukkan kekuatan sosial (via Wodak, 2001b:2). Pendapat Habermas tersebut diterjemahkan secara lebih luas oleh pakar yang lain, yaitu Halliday. Halliday berpendapat bahwa sebuah teks bukanlah teks semata, melainkan bahasa yang sedang melaksanakan tugas tertentu dalam konteks situasi. Dalam menganalisis teks, katanya, konteks menyatu di dalamnya dan tidak bisa dilepaskan (Halliday \& Hasan, 1992:13). Sejalan dengan hal ini pula, Fairclough mengatakan bahwa teks ialah ruang sosial tempat terjadinya secara bersamaan dua proses sosial yang mendasar, yaitu pemahaman dan pandangan terhadap dunia dan interaksi sosial (Fairclough, 1995:6).

Beberapa makalah tentang analisis wacana kritis dan representasi aktor sosial telah ditulis oleh para peminatnya. Mardikantoro dalam makalahnya tentang analisis wacana kritis terhadap tajuk korupsi di surat kabar mengatakan bahwa ada media yang menyatakan ketidaksetujuannya dengan berita tentang korupsi dengan menyajikan fakta kejanggalan dalam persidangan. Media lain setuju dengan menyajikan upaya penangkapan para pelaku korupsi (Mardikantoro, 2007).

Makalah lain tentang analisis wacana kritis program Sentilan Sentilun ditulis oleh Maemunah. Ia mengatakan bahwa ada sembilan aksi yang ditemukan dalam program tersebut. Dia kemudian menyimpulkan bahwa ideologi dalam praktik wacana tidak jauh berbeda dari ideologi bangsa (Maemunah, 2011).

Wahyuni menulis makalah tentang representasi pemerintah dalam wacana berita "Rupiah Loyo, Harga Bensin Segera Naik" di surat kabar Jawa Pos. Dia mengatakan bahwa teknik inklusi digunakan dalam pemberitaan. Teknik lain yang digunakan ialah diferensiasi dan indiferensiasi (Wahyuni, 2016).

Representasi aktor sosial dalam teks berita di situs Goal.com ditulis oleh Sidiq dalam bentuk tesis. Ia menemukan delapan belas strategi wacana dan delapan bentuk makna yang digunakan media dalam menampilkan aktor sosial dalam teks berita (Sidiq, 2016).

Skripsi tentang aktor sosial di koran Kedaulatan Rakyat dan Media Indonesia ditulis oleh Agustin. Ia berpendapat bahwa perbedaan struktur wacana dalam kedua teks di dua media tersebut paling menonjol terdapat di beberapa elemen, yakni tematik, skema, maksud, bentuk kalimat, koherensi, dan retoris (Fitria, 2017).

Representasi perempuan dalam lukisan di bagian belakang truk dibahas dalam makalah yang ditulis oleh Andalas dan Prihatini. Mereka menggunakan pendekatan wacana kritis dalam menganalisis data penelitian. Mereka menyimpulkan bahwa perempuan direpresentasikan secara negatif dalam hal yang berkaitan dengan cinta, uang, dan seks (Andalas \& Prihatini, 2018).

Dalam hal kajian tentang "kerajaankerajaan baru" di Nusantara, kiranya belum banyak penulis yang mengupasnya. Dalam rangka mengisi kekosongan itulah penulis mengetengahkan masalah ini. Selain untuk memperkaya rujukan teoretis, makalah ini juga dapat menambah wawasan tentang fenomena dan realitas sosial yang masih terjadi dalam masyarakat Indonesia, terutama yang berkaitan dengan realitas fisik faktual dan hal-hal yang berbau halusinasi dan imajinasi.

\section{METODE PENELITIAN}

Penulis menggunakan pendekatan kualitatif dalam makalah ini karena fenomena yang diteliti dilihat secara holistik dan analisisnya interpretatif (Creswell, 2003:182). Analisis dan pembahasan masalah dan data dalam makalah ini dilakukan secara kualitatif menggunakan 
narasi. Beberapa tabel mungkin digunakan untuk mempermudah penyajian. Dalam hal ini, penulis hanya menggunakan satu tabel untuk mendeskripsikan frekuensi kemunculan item.

Tahapan penelitian ini secara umum mengacu pada urutan proses yang direkomendasikan oleh Sudaryanto (Sudaryanto, 2015:6). Ia mengatakan bahwa tahapan penelitian terdiri atas tiga fase, yaitu penyediaan data, analisis data, dan penyajian hasil analisis.

Berdasarkan urutan proses itu pula, yang pertama dilakukan oleh penulis ialah menyediakan data penelitian. Penyediaan data dilakukan dengan teknik pengamatan dan pencatatan. Penulis menelusuri beberapa berita yang berhubungan dengan tujuan penelitian dan kemudian memutuskan dan memilih dua buah berita dari situs daring Kompas.com edisi 16 Januari 2020. Kedua berita tersebut berjudul "Fakta Raja Keraton Agung Sejagat, Buka Angkringan, Shooting Film Era Kerajaan, dan Dikukuhkan di Dieng" dan "Ratu Keraton Agung Sejagat Bertugas Rancang Pernak-pernik Kerajaan, Gunakan Uang Pendaftaran".

Setelah dipilih, tahap selanjutnya ialah memecah berita tersebut ke dalam kalimat-kalimat untuk memudahkan identifikasi siapa saja aktor sosial yang terlibat. Semua aktor sosial kemudian diinventarisasi dan dikelompokkan menjadi tiga, yaitu yang berhubungan langsung dengan atau mengacu kepada aktor/pelaku utama, korban, dan pihak lain.

Langkah selanjutnya ialah menganalisis dan mendefinisikan teknik yang digunakan oleh penulis berita dalam merepresentasikan para aktor sosial tersebut. Langkah terakhir ialah menyajikan hasil analisis dengan menguraikan dan membahas secara lebih mendalam untuk membuat simpulan.

\section{PEMBAHASAN}

Dua berita yang dipilih untuk kepentingan penulisan makalah ini memiliki kesamaan topik. Namun, satu berita menitikberatkan penyajian pada pelaku utama pria, yaitu Toto Santoso, sedangkan yang lain memfokuskan diri pada pelaku utama wanita, yaitu Fanni Aminadia.

Dua berita tersebut dirilis pada hari yang sama dan waktu yang berdekatan. Berita pertama dirilis pada pukul 5.45 WIB dan yang lain pada pukul 6.01 WIB. Keduanya disunting oleh orang yang sama, yaitu Rachmawati. Berikut disampaikan uraian dua berita dimaksud. Penomoran ini diharapkan dapat mempermudah proses identifikasi dan klasifikasi teknik yang digunakan penulis berita dalam merepresentasikan para aktor sosial.

1. Fakta Raja Keraton Agung Sejagat, Buka Angkringan, Shooting Film Era Kerajaan, dan Dikukuhkan di Dieng

2. Rabu (15/1/2020), raja dan ratu Keraton Agung Sejagat, Toto Santoso dan Fanni Aminadia, ditetapkan menjadi tersangka setelah ada motif penarikan dana dari masyarakat dengan cara tipu daya dengan simbol kerajaan.

3. Selain itu, diduga Toto telah melakukan penipuan terhadap warga dengan menyampaikan berita-berita bohong terkait sejarah kerajaan tersebut.

4. "Kami akan mendalami berapa banyak korban yang sudah mengumpulkan iuran dan motif lain yang akan kami ungkap," ujar Kapolda Jawa Tengah Irjen Rycko Amelda Daniel saat pengungkapan kasus di Mapolda Jateng, Rabu (15/1/2020).

5. Kabid Humas Polda Jawa Tengah Kombes Iskandar Sutisna menjelaskan, dari hasil penelusuran, polisi menemukan semua dokumen identitas yang dibuat di Keraton Agung Sejagat adalah palsu.

6. Semua dokumen palsu dibuat sendiri, dicetak sendiri.

7. Yang menentukan raja dan ratu juga dari mereka sendiri. 
8. "Atribut seragam dirancang sendiri oleh permaisuri," kata Iskandar di Mapolda Jateng, Rabu (15/1/2020).

9. Buka angkringan sejak 2018

10. Toto Santoso, sang raja Keraton Agung Sejagat, ternyata membuka angkringan di rumah kontrakannya di Sleman sejak tahun 2018.

11. Sehari-hari dia tinggal di kontrakan tersebut bersama keluarganya.

12. Lokasi angkringan berada di dalam halaman tepat di sebelah selatan rumah utama.

13. Bahkan saat Toto ditangkap, angkringan tersebut masih buka.

14. Pada tahun 2018, Toto bercerita ke perangkat desa mendirikan angkringan di kontrakan bersama komunitasnya.

15. Pak Toto kita panggil ke sini (kantor desa), kita minta penjelasan sebenarnya tempat itu mau digunakan untuk apa.

16. Beliau menjawab akan mengembangkan semacam usaha angkringan," ucap Sekretaris Desa Sidoluhur Fajar Nugroho, Rabu (15/1/2020).

17. Shooting ritual untuk kebutuhan konten YouTube

18. Toto Santoso pernah membuat ritual di rumah kontrakannya di Sleman yang ternyata untuk shooting film kolosal di kanal YouTube.

19. Saat shooting dilakukan, angkringan di halaman rumah sudah di-setting era kerajaan.

20. Karena curiga, pihak perangkat desa mendatangi dan menanyakan kegiatan yang dilakukan oleh Toto saat itu.

21. Namun, yang menjawab adalah Fanni Aminadia yang disebut sebagai istri Toto yang juga menjadi Ratu Keraton Agung Sejagat dengan sebutan Dyah Gitarja.

22. "Bu Fanni ini sangat canggih berkata-kata, waktu itu trennya YouTube.

23. Mereka mengatakan ingin menjadi YouTuber," kata Kasi Pemerintahan Desa Sidoluhur Adi Arya Pradana.

24. Bukan suami istri, hanya teman dekat.

25. Kapolda Jawa Tengah Irjen Rycko Amelda Daniel mengatakan bahwa status Fanni Aminadia (41) sebagai istri yang berperan sebagai Permaisuri Ratu Dyah Gitarja di Keraton Agung Sejagat ternyata palsu.

26. Rycko menyebut Toto dan Fanni bukan suami istri, tetapi hanya teman dekat.

27. Menurut Rycko, nama panggilan Dyah Gitarja dibuat saat Toto Santoso berperan sebagai raja Keraton Agung Sejagat yang namanya menjadi Toto Santoso Hadiningrat.

28. Sementara itu, Fanni Aminadia (41) berperan sebagai Permaisuri Ratu Dyah Gitarja.

29. Kasus raja dan ratu Keraton Agung Sejagat, menurut Rycko, adalah fenomena sosial yang mengganggu ketertiban masyarakat di sekitar desa di sana.

30. "Mulai sore kemarin, kami sudah meningkatkan tahap menjadi penyidikan," ujar Rycko.

31. Dikukuhkan saat musim embun es di Dieng.

32. Toto Santoso dikukuhkan menjadi raja di kawasan wisata Dataran Tinggi Dieng, Kabupaten Banjarnegara, tahun lalu.

33. Hal tersebut telah diceritakan oleh Kepala Unit Pengelola Teknis (UPT) Pengelolaan Objek Wisata Dieng Aryadi Darwanto.

34. "Pasti, karena namanya sama Pak Toto itu, ratunya juga sama, ada namanya.

35. Waktu itu sebelum prosesi mereka juga sempat bermalam di rumah tetua adat sini, dia dikasih pakaian kebesaran, masih disimpan sepertinya, karena ada rumbai-rumbai di belakang jadi enggak mau pakai," kata Aryadi.

36. Prosesi pengukuhan raja dan doa bersama memperingati 1.000 tahun Raja Sanjaya dilakukan sekitar pukul 22.00 WIB.

37. Aryadi mengingat saat itu sudah turun es karena dia memutuskan pulang karena kedinginan.

38. Kala itu ada 100 orang yang mengawali ritual di sumber mata air Bimalukar.

39. Dengan menggunakan kostum kerajaan dan iringan drumband, mereka berjalan kaki ke kompleks Candi Arjuna. 
40. Saat ritual itu dilakukan, ada beberapa aparat kepolisian dari Polda Jateng ikut mengamankan.

41. Kirab dimulai maghrib, sampai candi hampir pukul 20.00 WIB, jalan kaki dua jam, jaraknya hanya sekitar satu kilometer, tapi kan gerakannya satu langkah berhenti, berjalan berhenti.

42. "Musiknya seperti di Keraton Yogyakarta," tutur Aryadi.

43. Ratu Keraton Agung Sejagat Bertugas Rancang Pernak-pernik Kerajaan, Gunakan Uang Pendaftaran

44. Toto Santoso (42), Raja Keraton Agung Sejagat mengaku mendirikan kerajaan sekitar pertengahan 2018 lalu.

45. Namun ia tidak menyebutkan bulan dan tanggal awal kerajaan didirikan.

46. Saat itu ia mendapatkan ilham dari leluhur Raja Sanjaya keturunan dari Kerajaan Majapahit.

47. Dalam ilham tersebut, Toto diminta mendirikan Keraton Agung Sejagat di wilayah Kabupaten Purworejo dan meneruskan kejayaan Kerajaan Majapahit.

48. Ia kemudian merekrut warga sekitar yang berminat menjadi pejabat di kerajaannya.

49. Dilansir dari Tribun Jateng, Toto memberikan kepercayaan pada Fanni Aminadia (41) sebagai permaisuri Keraton Agung Sejagat.

50. Fanni bertugas merancang segala pernak-pernik kerajaan seperti seragam kerajaan, topi, umbul-umbul, tombak, dan bendera.

51. "Yang merancangnya Fanni. Ini kami dirikan sejak tahun lalu," kata Toto, Rabu $(15 / 1 / 2020)$.

52. Fanni disebut memiliki dua bisnis yakni salon kecantikan dan restoran.

53. Mereka berdua kemudian fokus mendirikan Keraton Agung Sejagat tanpa pekerjaan sampingan.

54. Untuk merancang segalanya, mereka menggunakan uang hasil iuran pendaftaran dari para calon pengikut.

55. Bersama pengikutnya, Toto mengaku telah tiga kali melakukan kirab.

56. Yang pertama pada 8 Desember 2018 lalu dan kirab kedua pada 10 Januari 2020.

57. Puncaknya adalah pada 12 Januari 2020.

58. Foto dan video kegiatan mereka kemudian viral di media sosial.

59. Kepada penyidik, Toto bercerita sedang mencari 13 menteri dari ratusan anggotanya.

60. Nanti itu, dia ingin menunjuk Resi (menteri) bagian politik, ekonomi, militer, sosial, dan budaya. Bawahan resi, ada bhre (gubernur).

61. "Lalu bawahnya lagi bekel (Lurah)," jelas Kabid Humas Polda Jateng, Kombes Pol Iskandar Fitriana.

62. Ia mengatakan anggota yang ingin menjadi bagian dari Keraton Agung Sejagat akan dikenai tiket sebesar Rp 3 juta hingga Rp 30 juta.

63. Jabatan yang didapatkan akan disesuaikan dengan biaya yang disetorkan kepada Toto dan Fanni.

64. "Apabila nominal tiket masuknya semakin besar atau tinggi, maka anggota tersebut akan diberikan jabatan yang tinggi dalam KAS," jelasnya.

65. Iskandar juga mengatakan bahwa Toto sempat hendak mendirikan kerajaan serupa di Yogyakarta pada tahun 2016 lalu dengan membentuk Jogjakarta Development Committee atau Jogja DEC.

66. Namun, warga di sana (Yogya) langsung menolak.

67. Kemudian, dia melakukan hal serupa di Purworejo.

68. "Anggotanya sampai 450 orang," jelasnya.

69. Saat ini polisi sedang mendalami kasus tersebut termasuk menghitung kerugian dan kemungkinan ada tersangka baru.

70. Sebab, dimungkinkan ada tersangka baru.

71. "Kita juga sedang mendalami hubungan antara Toto dan Fanni itu seperti apa," cetus Iskandar. 
Dua naskah berita yang telah terurai tersebut terdiri atas 71 item untaian informasi. Ada yang berbentuk konstruksi deklaratif, kutipan langsung, dan tak langsung. Berdasarkan hal itu, penulis mengidentifikasi representasi aktor sosial yang terlibat dan mengiventarisasinya dalam bentuk tabel di bawah ini

\begin{tabular}{|c|c|c|}
\hline Aktor sosial & Representasi & Frekuensi \\
\hline \multirow{30}{*}{ Pelaku } & Raja & 2 \\
\hline & Raja dan ratu Keraton Agung Sejagat & 1 \\
\hline & Toto Santoso & 6 \\
\hline & Fanni Aminadia & 5 \\
\hline & Tersangka & 1 \\
\hline & Toto & 8 \\
\hline & Mereka & 4 \\
\hline & Permaisuri & 1 \\
\hline & Sang Raja & 1 \\
\hline & Dia & 4 \\
\hline & Keluarganya & 1 \\
\hline & Komunitasnya & 1 \\
\hline & Pak Toto & 2 \\
\hline & Beliau & 1 \\
\hline & Istri Toto & 1 \\
\hline & Ratu Keraton Agung Sejagat & 1 \\
\hline & Raja Keraton Agung Sejagat & 2 \\
\hline & Dyah Gitarja & 2 \\
\hline & Bu Fanni & 1 \\
\hline & Permaisuri Ratu Dyah Gitarja & 2 \\
\hline & Toto dan Fanni & 3 \\
\hline & Suami istri & 1 \\
\hline & Teman dekat & 1 \\
\hline & Toto Santoso Hadiningrat & 1 \\
\hline & Ratunya & 1 \\
\hline & Ia & 3 \\
\hline & Kerajaannya & 1 \\
\hline & Fanni & 2 \\
\hline & Toto Santoso dan Fanni Aminadia & 1 \\
\hline & Istri & 1 \\
\hline \multirow[t]{4}{*}{ Korban } & Korban & 1 \\
\hline & Calon pengikut & 1 \\
\hline & Anggota & 1 \\
\hline & Pengikut & 1 \\
\hline \multirow[t]{14}{*}{ Aktor lainnya } & Kami & 2 \\
\hline & Kapolda Jawa Tengah Irjen Rycko Amelda Daniel & 2 \\
\hline & Kabid Humas Polda Jawa Tengah Kombes Iskandar Sutisna & 2 \\
\hline & Polisi & 1 \\
\hline & Iskandar & 2 \\
\hline & Sekretaris Desa Sidoluhur Fajar Nugroho & 1 \\
\hline & Perangkat desa & 2 \\
\hline & Kita & 3 \\
\hline & Kasi Pemerintahan Desa Sidoluhur Adi Arya Pradana & 1 \\
\hline & Rycko & 4 \\
\hline & Kami & 2 \\
\hline & Kepala Unit Pengelola Teknis (UPT) Pengelolaan Objek & \\
\hline & Wisata Dieng Aryadi Darwanto & 1 \\
\hline & Aparat kepolisian dari Polda Jateng & 1 \\
\hline
\end{tabular}




$\begin{array}{ll}\text { Aryadi } & 3 \\ \text { Dia } & 1 \\ \text { Penyidik } & 1 \\ \text { Tetua adat } & 1 \\ \text { Warga } & 2\end{array}$

Berdasarkan kompilasi data yang disajikan di atas, berikut diuraikan beberapa teknik yang digunakan oleh penulis berita dalam merepresentasikan para aktor sosial yang terlibat di wacana berita tersebut.

\section{Eksklusi dan Inklusi}

Menurut van Leeuwen, eksklusi digunakan ketika seorang aktor sosial tertentu tidak dibicarakan secara spesifik apa atau siapa dalam sebuah berita (van Leeuwen, 2008:28). Kata atau istilah digunakan biasanya berupa kata atau istilah generik yang tidak mengacu secara langsung kepada aktor sosial itu. Aktor sosial tidak disebutkan secara spesifik, tetapi merupakan bagian dari suatu entitas atau komunitas yang lebih besar.

Penggunaan teknik eksklusi di antaranya dapat dilihat dalam item nomor 11, 14, 20, 35, 40, dan 48. Dalam item-item itu tersua kata keluarganya, komunitasnya, perangkat desa, tetua adat, dan pengikut. Dalam item nomor 11, misalnya, tersua kata keluarganya dalam konstruksi Seharihari dia tinggal di kontrakan tersebut bersama keluarganya. Akhiran \{-nya $\}$ yang dimaksud di sini tentu mengacu kepada Toto. Kata keluarganya muncul untuk menandai adanya teknik eksklusi, yaitu dengan tidak menyajikan secara spesifik siapa saja yang dimaksud dengan keluarganya tersebut. Dalam item nomor 48, dijumpai frasa calon pengikut dalam konstruksi Untuk merancang segalanya, mereka menggunakan uang hasil iuran pendaftaran dari para calon pengikut. Karena dieksklusikan, siapa saja yang tercakupi dalam kata pengikut tidak ditampilkan secara tersurat. Secara lebih spesifik, Leeuwen menyebut teknik ini sebagai teknik supression (van Leeuwen, 2008:29).
Sementara itu, inklusi merupakan kebalikan dari eksklusi. Inklusi terjadi ketika aktor sosial dilibatkan dan diacu secara langsung dalam pembicaraan. Beberapa contoh inklusi ialah semua aktor sosial yang direpresentasikan dengan nama diri dan/atau nama jabatannya, misalnya Toto Santoso, Fanni Aminadia, Kapolda Jawa Tengah; dan beberapa pronomina, misalnya beliau, kami, kita, mereka, dia, dan $i a$, yang antara lain dapat dilihat dalam item nomor 2, 4, 8, 16, 23, 25, 27, 60, dan 64. Penggunaan nama diri dan nama jabatan serta kata ganti orang tersebut disebutkan secara eksplisit dalam pembicaraan.

Dalam item nomor 23, misalnya, dijumpai informasi spesifik tentang seorang perangkat di desa tempat Toto dan Fanni tinggal. Nama Adi Arya Pradana diterangkan dengan sangat jelas beserta jabatannya, yaitu Kepala Seksi Pemerintahan Desa Sidoluhur, dijelaskan secara gamblang dalam konstruksi "Mereka mengatakan ingin menjadi YouTuber," kata Kasi Pemerintahan Desa Sidoluhur Adi Arya Pradana. Penulis berita sudah memastikan dengan akurat identitas aktor sosial tersebut sehingga menggunakan teknik inklusi dalam kalimatnya.

Dalam pemberitaan atau dalam konteks bahasa laras jurnalistik, penyebutan nama seseorang dilakukan jika informasi yang berkaitan dengan orang itu terkonfirmasi dengan baik. Jika belum terkonfirmasi, penggunaan istilah oknum atau penyebutan inisial nama biasanya diprioritaskan.

\section{Generalisasi dan Spesifikasi}

Teknik ini mengacu kepada bagaimana aktor sosial dinyatakan secara umum atau spesifik. Terjadi kecenderungan dalam gaya bahasa media massa cetak dan elektronik, penyebutan aktor sosial yang berkaitan 
dengan otoritas setempat diwujudkan dengan teknik spesifikasi lengkap dengan jabatan dan nama lengkap mereka. Namun, aktor sosial lain, dalam hal ini masyarakat umum, apalagi pihak yang tidak terkait langsung dengan sebuah peristiwa, diwujudkan dengan teknik generalisasi.

Teknik generalisasi dapat dijumpai misalnya pada konstruksi item nomor 5, 14, 20, 30, 40, 48, 68, dan 70. Pada contoh item nomor 5, kata polisi dalam konstruksi Kabid Humas Polda Jawa Tengah Kombes Iskandar Sutisna menjelaskan, dari hasil penelusuran, polisi menemukan semua dokumen identitas yang dibuat di Keraton Agung Sejagat adalah palsu menandai digunakannya teknik generalisasi.

Dalam item nomor 5 tersebut identitas polisi yang menemukan tidak dijelaskan secara eksplisit. Hal ini menandai bahwa kalimat ini menitikberatkan fokus kepada pelaku sebagai bagian dari komunitas atau kesatuan yang lebih besar, yaitu kepolisian. Representasi aktor sosial dengan menggunakan teknik ini dilakukan untuk memberikan informasi tentang siapa saja aktor sosial utama yang terlibat dalam wacana berita. Namun, dengan pertimbangan tertentu, penulis tidak menampilkan secara terperinci identitas aktor sosial tersebut.

Teknik spesifikasi dapat dijumpai antara lain pada item nomor 1, 2, 10, 16, 21, 25, 33, dan 60. Pada item nomor 21 yang berbunyi Namun, yang menjawab adalah Fanni Aminadia yang disebut sebagai istri Toto yang juga menjadi Ratu Keraton Agung Sejagat dengan sebutan Dyah Gitarja, identitas Fanni dijelaskan secara mendetail dan spesifik. Ia direpresentasikan sebagai dirinya, statusnya sebagai istri Toto, dan jabatannya sebagai ratu.

\section{Aktivasi dan Pasivasi}

Teknik aktivasi dan pasivasi dimasukkan ke dalam konsep alokasi peran oleh van Leeuwen (van Leeuwen, 2008:32). Aktivasi mengacu kepada representasi aktor sosial yang dikaitkan dengan apa yang mereka lakukan, merupakan aktor utama dalam sebuah aktivitas. Aktor sosial biasanya muncul dalam sebuah konstruksi aktif sebagai subjek pelaku. Hal tersebut dapat dijumpai antara lain pada konstruksi item nomor $3,4,5,10,23,25,48,50,53,61,64$, 66, 68 dan 70 .

Konstruksi item nomor 25, misalnya, yang berbunyi Kapolda Jawa Tengah Irjen Rycko Amelda Daniel mengatakan bahwa status Fanni Aminadia (41) sebagai istri yang berperan sebagai Permaisuri Ratu Dyah Gitarja di Keraton Agung Sejagat ternyata palsu merupakan kalimat aktif yang berpola SPO. Subjek diisi oleh bentuk Kapolda Jawa Tengah Irjen Rycko Amelda Daniel, predikat diisi oleh verba mengatakan, dan objek diisi oleh anak kalimat bahwa status Fanni Aminadia (41) sebagai istri yang berperan sebagai Permaisuri Ratu Dyah Gitarja di Keraton Agung Sejagat ternyata palsu. Penggunaan kalimat aktif, salah satu pertimbangan pokoknya, ialah subjek pelaku dan apa yang dilakukannya diketahui secara pasti. Identitas subjek telah terkonfirmasi sehingga penulis berita menampilkannya secara tersurat dan jelas. Jika identitas subjek pelaku belum dikonfirmasi, informasi biasanya disampaikan dalam bentuk kalimat pasif.

Pada sisi lain, pasivasi mengacu kepada representasi aktor sosial yang menjadi objek atau penderita dalam sebuah konstruksi. Penggunaan bentuk pasif, yang memungkinkan absennya subjek pelaku, dimungkinkan jika pelaku belum teridentifikasi secara jelas. Hal tersebut dapat dijumpai antara lain dalam contoh item nomor 2, 6, 31, 32, 62, dan 69 .

Item nomor 32, misalnya, yang berbunyi Toto Santoso dikukuhkan menjadi raja di kawasan wisata Dataran Tinggi Dieng, Kabupaten Banjarnegara, tahun lalu merupakan kalimat pasif dan berpola SPPelK. Toto dalam hal ini merupakan subjek pengalam, bukan subjek pelaku. 
Subjek pelakunya ialah para pengikut Toto yang mengukuhkannya menjadi raja. Dalam konteks kalimat pasif, pelaku boleh tidak dimunculkan dan tidak mengganggu keseluruhan konstruksi.

\section{Nominasi dan Kategorisasi}

Nominasi mengacu kepada penyebutan aktor sosial dengan dilengkapi identitas khusus mereka. Nominasi dapat muncul berupa nama diri, jabatan, dan kadangkadang sapaan. Contoh nominasi antara lain dapat dilihat pada konstruksi item nomor 2, 8, 18, 20, 22, 38, dan 60 .

Item nomor 60 , misalnya, berbunyi "Nanti itu, dia ingin menunjuk Resi (menteri) bagian politik, ekonomi, militer, sosial, dan budaya. Bawahan resi, ada bhre (gubernur). Lalu bawahnya lagi bekel (Lurah)," jelas Kabid Humas Polda Jateng, Kombes Pol Iskandar Fitriana. Ada teknik nominasi yang digunakan dalam kalimat itu, yaitu Kabid Humas Polda Jateng, Kombes Pol. Iskandar Fitriana, berupa nama diri, pangkat, dan jabatan.

Kategorisasi mengacu kepada penggambaran aktor sosial berdasarkan identitas umum mereka. Contoh kategorisasi dapat dilihat antara lain pada item nomor 3, 4, 20, 38, 40, 55, dan 59.

Item nomor 40 yang berbunyi Saat ritual itu dilakukan, ada beberapa aparat kepolisian dari Polda Jateng ikut mengamankan. "Kirab dimulai maghrib, sampai candi hampir pukul 20.00 WIB, jalan kaki dua jam, jaraknya hanya sekitar satu kilometer, tapi kan gerakannya satu langkah berhenti, berjalan berhenti. Musiknya seperti di Keraton Yogyakarta," tutur Aryadi memiliki aktor sosial yang direpresentasikan dengan teknik kategorisasi. Aktor sosial yang dimaksud ialah beberapa aparat kepolisian dari Polda Jateng. Para polisi tersebut direpresentasikan berdasarkan kesatuannya dan tidak dijelaskan secara terperinci siapa saja personel yang mengamankan kirab tersebut.

\section{Personalisasi}

Personalisasi mengacu kepada representasi para aktor sosial sebagai manusia biasa. Penggunaan pronomina dan kata ganti milik biasanya yang paling sering dimunculkan. Contoh personalisasi dapat dilihat antara lain pada contoh konstruksi item nomor 11, 16, 45, 46, 60, 61, dan 66.

Dalam item nomor 16 yang berbunyi Beliau menjawab akan mengembangkan semacam usaha angkringan," ucap Sekretaris Desa Sidoluhur Fajar Nugroho, Rabu (15/1/2020) ditemui penggunaan pronomina beliau yang menunjukkan adanya teknik personalisasi. Kata beliau yang mengacu kepada Toto digunakan oleh Sekretaris Desa Sidoluhur, Fajar Nugroho. Pada kesempatan lain, pronomina yang mengacu kepada Toto dihadirkan dalam bentuk dia (item nomor 11,60) dan ia (item nomor 45, 46, 61, dan 66).

Berdasarkan inventarisasi teknik merepresentasikan aktor sosial yang ditampilkan di atas, terlihat cukup jelas bahwa penulis memfokuskan penyajian beritanya pada pelaku utama, yaitu Toto Santoso dan Fanni Aminadia. Cukup banyak representasi yang mengacu kepada kedua aktor tersebut.

Sudut pandang yang digunakan penulis biasanya berpengaruh terhadap fokus dan pesan dari keseluruhan berita yang dituliskan. Berdasarkan dua contoh berita dan teknik yang digunakan dalam merepresentasikan para aktor sosial di atas, penulis berita rupanya memilih sudut pandang pelaku. Dengan demikian, pemberitaan secara mayoritas difokuskan kepada pelaku.

Gaya menonjolkan pelaku seperti yang digunakan dalam dua berita di atas memiliki tujuan tertentu. Pertama, penulis ingin menyampaikan informasi yang sejelas-jelasnya tentang siapa sebenarnya pelaku, bagaimana pelaku melakukan semua aksinya, dan apa yang melatarbelakangi aksi tersebut.

Tujuan pertama sepertinya telah tercapai dengan digunakannya berbagai 
macam representasi yang mengacu kepada pelaku. Identitas pelaku utama pria, Toto Santoso, tergambar secara jelas dalam dua berita tersebut. Perannya baik sebagai pribadi maupun raja di keraton yang didirikannya terwakili dengan cukup komprehensif dan terperinci. Latar belakang kehidupan pribadinya hingga kronologi pembentukan keraton digambarkan secara tersurat.

Begitu pula peran sang ratu. Identitas Fanni Aminadia yang juga berperan sebagai pelaku utama tergambar secara jelas dalam berita itu. Latar belakangnya sebagai pribadi dan sebagai sang ratu direpresentasikan dengan cukup lengkap. Bahkan, perannya sebagai sang ratu tergambar secara detail dalam dua berita tersebut.

Dengan ungkapan lain, para aktor sosial utama yang terlibat dalam dua berita tersebut secara gamblang diinklusikan oleh penulis berita. Keterlibatan mereka dalam pemberitaan menempati porsi yang cukup besar. Toto dan Fanni dihadirkan kembali dalam pemberitaan dengan berbagai teknik.

Pemfokusan kepada dua tokoh utama dengan merepresentasikannya secara dominan menunjukkan bahwa penulis berita ingin memberi tahu masyarakat, dalam hal ini pembaca, bahwa para tokoh utama berasal dari kalangan masyarakat biasa, bukan pejabat atau penguasa. Penulis berita berusaha "mendekatkan" pembaca dengan sosok dan identitas aktor sosial utama, Toto dan Fanni. Oleh karena itu, berbagai teknik digunakan untuk merepresentasikan mereka.

Proses mendekatkan pembaca kepada aktor sosial itu berkaitan dengan tujuan kedua, yaitu mengungkapkan adanya fenomena sosial yang ada dan hidup di tengah masyarakat itu sendiri. Adanya berbagai macam "kerajaan" baru yang muncul hampir secara bersamaan menunjukkan adanya penyakit sosial atau minimal gejala yang mengindikasikan adanya penyakit sosial. Kemunculan "kerajaan-kerajaan" baru tersebut dianggap sebagai pelampiasan atau manifestasi ketidakpuasan masyarakat terhadap penguasa. Mereka ingin mewujudkan struktur kekuasaan sendiri untuk menyelesaikan masalah-masalah sosial yang dihadapinya.

Penangkapan para aktor utama Keraton Agung Sejagat mengindikasikan beberapa hal. Yang pertama berkaitan dengan ketertiban umum. Salah satunya ialah masalah iuran keanggotaan. Iuran yang wajib dibayarkan setiap calon anggota dan kemudian menentukan jabatan yang didudukinya dianggap sebagai sebuah upaya penipuan sehingga meresahkan masyarakat.

Hal kedua ialah bahwa kegiatan pendirian Keraton Agung Sejagat ternyata tidak memiliki landasan yang sah. Forum Silaturahmi Keraton Nusantara menganggap asal usul Keraton Agung Sejagat tidak jelas dan tidak memiliki keterkaitan dengan kerajaan apa pun di Nusantara.

Penulis berita ingin menunjukkan bahwa masyarakat yang tidak puas dengan pemerintah atau dengan struktur/sistem sosial yang berlaku dapat melayangkan protes dan kritiknya dengan cara yang baik dan tidak dengan cara yang bertentangan dengan hukum. Jika caranya kurang pantas dan bahkan mungkin bertentangan dengan hukum, kriminalisasi dapat dikenakan kepada mereka.

Secara tidak langsung berita tersebut juga menyasar kepada penguasa. Penulis berita, seperti yang dilakukan oleh pelaku dalam berita itu, ingin menunjukkan bahwa masih ada masyarakat yang tidak puas dengan situasi yang terjadi selama ini. Pembangunan yang dilaksanakan dinilai belum menyentuh cita-cita hidup sejahtera yang didambakan oleh seluruh masyarakat. Berita tersebut juga dapat menjadi kritik terhadap pemerintah bahwa program pembangunan semestinya dilakukan secara terstruktur dan merata serta tanpa mengecewakan golongan masyarakat tertentu. 
Sementara itu, para aktor sosial yang lain dianggap sebagai "peran pendamping" dalam dua berita tersebut. Mereka dieksklusikan dan tidak terlalu diinklusikan. Bahkan, kadang-kadang disebutkan sepintas lalu saja. Keluarga dan komunitas yang mengacu kepada Toto dan beberapa polisi yang menangani kasus itu dihadirkan dengan, misalnya, teknik generalisasi dengan menyebut mereka secara umum berdasarkan kesatuannya dan teknik pasivasi dengan melesapkannya. Penulis berita menganggap masyarakat atau pembaca sudah maklum akan peran para aktor sosial itu.

Hal lain yang dapat dilihat dari uraian di atas ialah penulis berita dapat saja merepresentasikan aktor sosial yang sama dengan teknik yang berbeda. Pelaku utama, Fanni, misalnya, direpresentasikan dengan teknik spesifikasi berupa nama diri dan ciri spesifiknya. Namun, di bagian lain berita itu, teknik spesifikasi tidak lagi digunakan. Penulis berita menggunakan teknik lain, misalnya nominasi dan personalisasi. Semua teknik yang digunakan tersebut tentu masih mengacu kepada orang yang sama, yaitu Fanni.

Variasi teknik merepresentasikan aktor sosial yang dilakukan oleh penulis berita sebenarnya tidak diatur terlalu ketat. Penggunaan teknik yang berbeda terhadap aktor yang sama dimungkinkan sebagai bagian dari upaya untuk mewujudkan efek keterwakilan yang spesifik (van Leeuwen, 2008:51).

Berdasarkan beberapa asumsi di atas, penulis dapat mengambil beberapa simpulan berikut. Penulis berita memiliki hak atas apa yang ingin disampaikannya lewat media. Bagaimana penulis menyajikan berita dan memilih sudut pandang pemberitaan tentu berkaitan dengan kebijakan strategis redaksi dan bagaimana penulis berita ingin melibatkan atau mendekatkan pembaca kepada para aktor sosialnya.

Simpulan berikutnya berkaitan dengan penggolongan yang dilakukan oleh van Leeuwen mengenai tiga tipe transformasi dalam merepresentasikan aktor sosial, yaitu delesi atau penghilangan, penataulangan, dan substitusi (van Leeuwen, 2008:53). Teknik eksklusi dan inklusi termasuk ke dalam kelompok delesi; aktivasi dan pasivasi termasuk ke dalam kelompok penataulangan; dan personalisasi, generalisasi, spesifikasi, kategorisasi, dan nominasi termasuk ke dalam kelompok substitusi.

\section{PENUTUP}

Media massa berperan sangat penting dalam semua era yang telah dijalani oleh Republik ini. Media massa berperan sangat vital dalam revolusi diplomatik dan fisik yang terjadi sebelum dan setelah kemerdekaan. Media massa juga menjadi corong bagi dunia bahwa bangsa ini masih ada dan kemudian merdeka sebagai buah perjuangannya sendiri.

Salah satu fungsi lain dari media massa ialah fungsi pendidikan dan pembelajaran. Media massa harus mampu menjadi alat untuk mencerdaskan dan meningkatkan kualitas hidup masyarakat pembacanya. Informasi yang disampaikan kepada khalayak harus merupakan informasi yang mencerdaskan dan mampu membuka wawasan pembacanya yang selanjutnya dapat digunakan untuk meningkatkan kualitas hidup.

Pemberitaan di media massa merupakan sajian fakta yang dipadukan dengan ideologi dan kebijakan redaksi. Dengan demikian, berita yang dibaca oleh masyarakat bukanlah berita yang sepenuhnya netral, melainkan memiliki berbagai muatan kepentingan. Namun, satu hal yang tidak boleh dilupakan ialah masyarakat memerlukan berita yang benar, akurat, dan bertanggung jawab. Media massa wajib memenuhi hal tersebut dengan seproporsional dan sejujur mungkin.

Berkaitan dengan masalah yang dibahas dalam makalah ini, teknik yang digunakan penulis berita ialah eksklusi, 
inklusi, aktivasi, pasivasi, generalisasi, spesifikasi, nominasi, kategorisasi, dan personalisasi. Teknik yang digunakan penulis dalam menyajikan semua aktor sosial yang tampil di sebuah berita menentukan keseluruhan isi dan interpretasi berita. Dengan mengambil sudut pandang pelaku, penulis ingin mengetengahkan sejelas-jelasnya identitas pelaku. Dari sisi

\section{DAFTAR PUSTAKA}

Andalas, E. F., \& Prihatini, A. (2018). Representasi Perempuan dalam Tulisan dan Gambar Bak Belakang Truk: Analisis Wacana Kritis Multimodal Terhadap Bahasa Seksis. Satwika, 2(1), 1-19. Retrieved from http://ejournal.umm.ac.id/index.php/JI CC/article/view/7018/6398

Creswell, J. W. (2003). Research Design: Qualitative, Quantitative and Mixed Method Approach. California: Sage Publications.

Fairclough, N. (1995). Critical Discourse Analysis: The Critical Study of Language. New York: Longman.

Fitria, N. A. (2017). Analisis Teks Berita Terkait Representasi Aktor pada Koran Kedaulatan Rakyat dan Media Indonesia: Studi Analisis Wacana Teun A. Van Dijk mengenai Anies Baswedan dalam Isu Ujian Nasional (Universitas Pendidikan Indonesia). Retrieved from http://repository.upi.edu/30142/

Halliday, M. A. K., \& Hasan, R. (1992). Bahasa, Konteks, dan Teks; Aspekaspek Bahasa dalam Pandangan Semiotik Sosial. Yogyakarta: UGM.

Maemunah, E. (2011). Analisis Wacana Kritis terhadap Acara Sentilan Sentilun di Metro TV. Jalabahasa, $7(2), 21-32$.

Mardikantoro, H. B. (2007). Pergeseran Bahasa Jawa dalam Ranah Keluarga pada Masyarakat Multibahasa di Kabupaten Brebes. Humaniora, XIX(1), 43-51. yang lain, penulis berita secara tidak langsung juga menyajikan fenomena sosial yang kerap terjadi di masyarakat. Adanya kesenjangan dan ketimpangan sosial merupakan pemicu atas segala masalah yang timbul dan berujung pada ekspresi sikap yang dilakukan secara tidak proporsional.

Mayr, A. (2008). Introduction: Power, Discourse and Institutions. In A. Mayr (Ed.), Language and Power (pp.1-25). https://doi.org/10.1177/007542421245 9055

Mills, S. (1997). Discourse. London: Routledge.

Sidiq, A. N. (2016). Analisis Wacana Kritis Mengenai Representasi Aktor Sosial Dalam Teks Berita Pada Situs Goal.com/FR (Universitas Brawijaya). Retrieved from http://repository.ub.ac.id/102309/

Sobur, A. (2002). Analisis Teks Media. Bandung: Remaja Rosda Karya.

Sudaryanto. (2015). Metode dan Aneka Teknik Analisis Bahasa. Yogyakarta: Sanata Darma University Press.

van Leeuwen, T. (2008). Discourse and Practice. Oxford: Oxford University Press.

Wahyuni, S. (2016). Representasi Pemerintah dalam Wacana "Rupiah Loyo, Harga Bensin Segera Naik" di Koran Jawa Pos. Sawerigading, 22(2), 281-290.

Wodak, R. (2001a). The DiscourseHistorical Approach. In R. Wodak \& M. Meyer (Eds.), Methods of Critical Discourse Analysis. London: Sage Publications.

Wodak, R. (2001b). What CDA is about - a summary of its history, important concepts and its developments. In R. Wodak \& M. Meyer (Eds.), Method of Critical Discourse Analysis (pp. 2-9). London: Sage Publications. 